Supplement of Clim. Past Discuss., 11, 5073-5111, 2015

http://www.clim-past-discuss.net/11/5073/2015/

doi:10.5194/cpd-11-5073-2015-supplement

(C) Author(s) 2015. CC Attribution 3.0 License.

(c) (1)

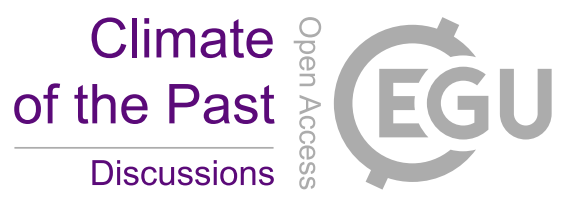

Supplement of

\title{
Optimal site selection for a high resolution ice core record in East Antarctica
}

T. Vance et al.

Correspondence to: T. Vance (tessa.vance@utas.edu.au)

The copyright of individual parts of the supplement might differ from the CC-BY 3.0 licence. 


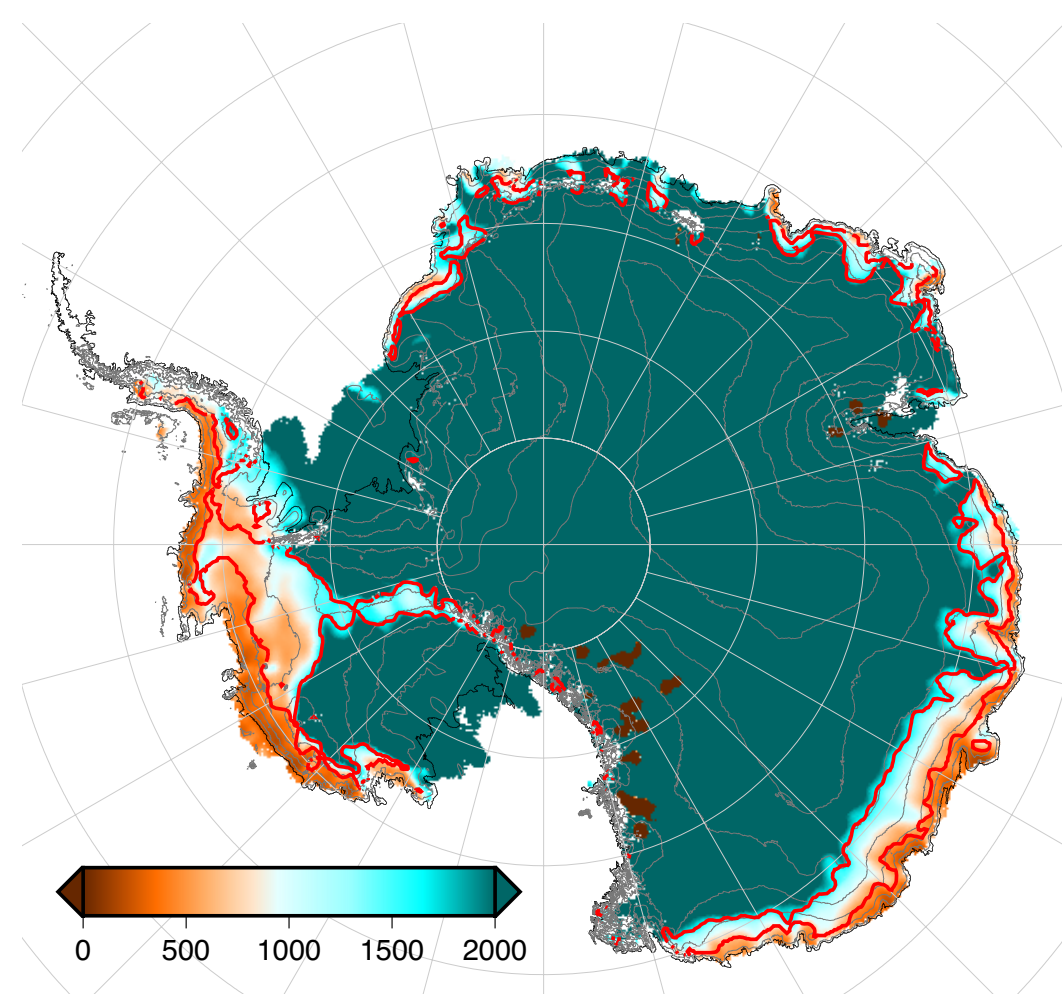

Figure S1.

Assessing continental Antarctica for areas that show potential for high resolution ice core sites. The colour bar shows ice age at $300 \mathrm{~m}$ depth using the annual average (1979-2012) surface mass balance data from RACMO2.1/ANT (Lenaerts et al., 2012). The mass balance data was converted to ice equivalent depth (ice density of 917 $\mathrm{kg} \mathrm{m}^{-3}$ and a Nye vertical strain rate profile (Nye1963) based on the BEDMAP2 ice thickness compilation (Fretwell et al., 2013) was applied. A red boundary shows regions that have an ice age of $>500$ years at $300 \mathrm{~m}$ depth, receive $>200 \mathrm{~mm} \mathrm{y}^{-1} \mathrm{IE}$ and are above the 1000 m contour. 


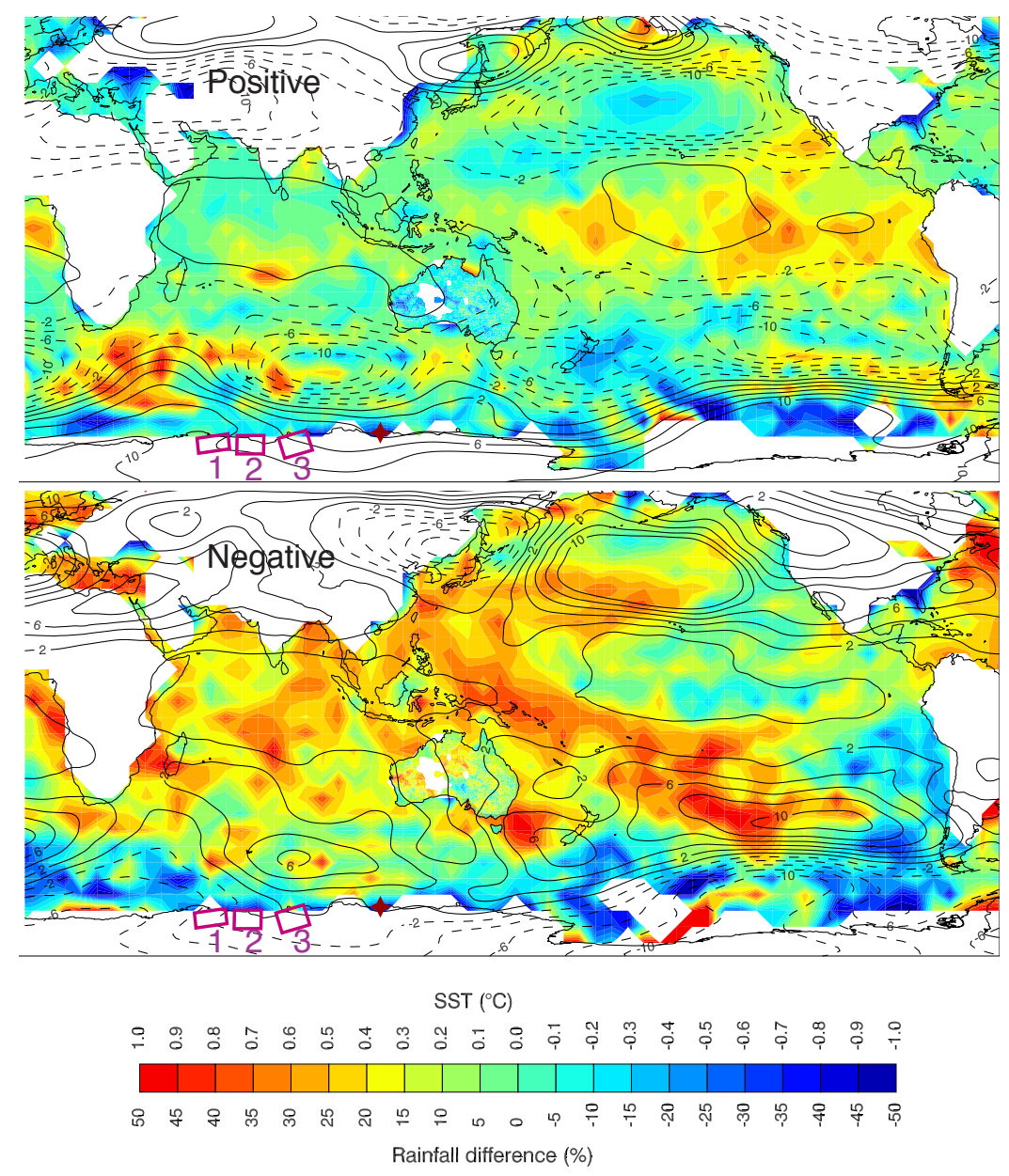

Figure S2.

Sea surface temperature, 500 metre geopotential height and Australian rainfall correlation analysis with the IPO during the warm season (November-March) for positive (top) and negative (bottom) IPO years over the ERA-Interim period of 19792014. Positive and negative years were defined as for Figure 7 ( 0.5 std deviation above or below average). Note the colourbar defines a rainfall increase over Australia, as well as warm SSTs, as the red spectrum (conversely, a rainfall decrease and cool SSTs are blue). The three regions identified in fuschia are regions shown in previous figures: 1 - Law Promontory/Enderby Land, 2 - Cape Darnley and 3 - Mt Brown. Law Dome is shown as a red star on the coast to the east of the three possible sites. 